\title{
A Theory of Negligence for Constitutional Torts
}

In Monroe v. Pape, ${ }^{1}$ the Supreme Court held that the existence of a state common law remedy does not foreclose a section $1983^{2}$ damage action in federal court where state or local officials, acting under color of state law, violate federal constitutional rights. ${ }^{3}$ Despite the distinction between common law torts and constitutional torts adumbrated in Monroe, ${ }^{4}$

1. 365 U.S. 167 (1961).

2. The full section reads:

Every person who, under color of any statute, ordinance, regulation, custom, or usage, of any State or Territory or the District of Columbia, subjects, or causes to be subjected, any citizen of the United States or other person within the jurisdiction thereof to the deprivation of any rights, privileges, or immunities secured by the Constitution and laws, shall be liable to the party injured in an action at law, suit in equity, or other proper proceeding for redress. For the purposes of this section, any Act of Congress applicable exclusively to the District of Columbia shall be considered to be a statute of the District of Columbia.

42 U.S.C. § 1983 (Supp. V 1981).

This Note is concerned only with section 1983 damage claims. This statute, however, serves as a basis for injunctive relief as well. See Doran v. Salem Inn, Inc., 422 U.S. 922 (1975); Allee v. Medrano, 416 U.S. 802 (1974). Additionally, this Note deals only with deprivations of constitutional rights. For a discussion of statutory claims under section 1983, see Middlesex County Sewerage Auth. v. National Sea Clammers Ass'n, 453 U.S. 1, 19 (1981).

3. 365 U.S. at 183. The federal counterpart of the section 1983 damage action against state and local officials is the Bivens action, by which federal governmental officials may be held liable for constitutional torts. See Bivens v. Six Unknown Named Agents of the Fed. Bureau of Narcotics, 403 U.S. 388 (1971). This Note's proposal is intended to apply equally to section 1983 claims and Bivens actions. Their conceptual parallels have been widely recognized. See, e.g., Carlson v. Green, 446 U.S. 14, 24-25 (1981) (common goal of deterring constitutional violations); Butz v. Economou, 438 U.S. 478, 496-504 (1978) (same qualified immunity for section 1983 and Bivens defendants); G.M. Leasing Corp. v. United States, 560 F.2d 1011, 1015 (10th Cir. 1977) (same qualified immunity), cert. denied, 435 U.S. 923 (1978); Paton v. La Prade, 524 F.2d 862, 871-72 (3d Cir. 1975) (same types of injuries covered). Moreover, although what is presented as statutory interpretation in the context of a section 1983 action is technically federal common law in the context of a Bivens action, federal courts are plainly competent to develop federal common law in cases concerning federal statutory or constitutional rights. See UAW v. Hoosier Cardinal Corp., 383 U.S. 696, 701-05 (1966); Holmberg v. Armbrecht, 327 U.S. 392,395 (1946). Section 1983, as the federal statute dealing with the general subject matter of the Bivens action, is the appropriate starting point for such development. Cf. Wallis v. Pan Am. Petroleum Corp., 384 U.S. 63, 69 (1966) (creation of common law rule begins with examination of applicable federal statute).

4. Justice Harlan's concurrence in Monroe makes this distinction explicit:

The statute becomes more than a jurisdictional provision only if one attributes to the enacting legislature the vicw that a deprivation of a constitutional right is significantly different from and more serious than a violation of a state right and therefore deserves a different 


\section{constitutional tort theory has yet to develop a set of principles analytically} independent from those of its common law counterpart. ${ }^{5}$

The particular concern of this Note is the absence of a theory that can explain the role of negligence ${ }^{6}$ in constitutional tort actions against supervisory defendants. ${ }^{7}$ The Note argues that a negligence standard to govern supervisory liability is essential to the development of a constitutional tort theory that is principled in its imposition of liability and comprehensive in its protection..$^{8}$ Yet the "reasonable person" standard, which generally

remedy even though the same act may constitute both a state tort and the deprivation of a constitutional right.

365 U.S. at 196 (Harlan, J., concurring); cf. Screws v. United States, 325 U.S. 91, 108 (1945) (plurality opinion) ("The fact that [the action] is also a violation of state law does not make it any less a federal offense punishable as such.").

5. Common law concepts guide the analysis of a variety of constitutional tort elements. Defenses to constitutional tort claims are fashioned by reference to those available at common law. See Pierson v. Ray, 386 U.S. 547, 555 (1967) ("[W]e presume that Congress would have specifically so provided had it wished to abolish the [common law good faith defense] doctrine."). Compensation, the most prominent goal of common law tort actions, has been established as the measure by which constitutional tort damages are determined as well. See Carey v. Piphus, 435 U.S. 247, 254-55 (1978). In addition, the elements of various constitutional violations are frequently discussed in common law terminology. See, e.g., Estelle v. Gamble, 429 U.S. 97, 107 (1976) (rejecting idea of Eighth Amendment "medical malpractice" claim); Pierson v. Ray, 386 U.S. 547, 557 (analogizing Fourth Amendment claim against police officers to common law false arrest action); Whirl v. Kern, 407 F.2d 781, 790-91 (5th Cir.) (Fourth Amendment "false imprisonment" claim), cert. denied, 396 U.S. 901 (1969); cf. Bryan v. Jones, 530 F.2d 1210, 1213-15 (5th Cir.) (criticizing Whirl's strict liability approach to jailer liability for erroneous imprisonment), cert. denied, 429 U.S. 865 (1976).

6. The lower federal courts have responded in differing ways to complaints alleging the negligent deprivation of constitutional rights. Compare Withers v. Levine, 615 F.2d 158 (4th Cir.) (liability where inmate's injury caused by prison administrator's negligence in making cellmate assignments in the face of pervasive risk of inmate brutality toward one another), cert. denied, 449 U.S. 849 (1980) and Johnson v. Duffy 588 F.2d 740 (9th Cir. 1978) (liability where inmate harmed by sheriffs omission to perform statutory duties) and Carter v. Carlson, 447 F.2d 358 (D.C. Cir. 1971) (high level police officials may be liable for negligent failure to train and supervise officers), rev'd on other grounds sub nom. District of Columbia v. Carter, 409 U.S. 418 (1973) with Hays v. Jefferson County, 668 F.2d 869, 874 (6th Cir.) (supervisors not liable for simple negligence in training, supervising, and controiling police officers), cert. denied, 103 S. Ct. 75 (1982) and Adams v. Pate, 445 F.2d 105, 107 (7th Cir. 1971) (affirming dismissal of complaint against warden where no allegation that he had directed acts or that they were done with his knowledge and consent) and Madison v. Gerstein, 440 F.2d 338 (5th Cir. 1971) (same).

The Supreme Court has observed that "[n]othing in the language of $\S 1983$ or its legislative history limits the statute solely to intentional deprivations of constitutional rights." Parratt v. Taylor, 451 U.S. 527, 534 (1981). It has also indicated, however, that the question of the sufficiency of negligence "may well not be susceptible of a uniform answer across the entire spectrum of conceivable constitutional violations." Id. at 534 (quoting Baker v. McCollan, 443 U.S. 137, 139-40 (1979)).

7. As used in this Note, "supervisory liability" is intended to include the liability not only of individual supervisors, but also of public agencies and entities.

8. The absence of any comprehensive approach to supervisory responsibility and the confusion over the status of negligent wrongs may be attributed, at least in part, to judicial uncertainty as to the extent to which Congress has sanctioned judicial oversight of executive authority. Before the Court held in Monell v. Department of Social Servs., 436 U.S. 658 (1978), that municipalities were "persons" subject to section 1983 liability, committees in both the 95th and 96th Congresses considered versions of a bill that would have greatly expanded municipal liability. The proposed Civil Rights Improvement Act of 1977 would have imposed liability on municipalities and their agencies when officers or employees

directly responsible for the conduct of the subordinate officer or employee who committed such 
monitors the social obligations of individuals at common law, is ill-suited to gauge the governmental action that is at issue in a constitutional tort suit. ${ }^{9}$ The Note proposes that when a plaintiff sues a public agency or its responsible officers for the acts of a front-line employee, the organizational procedures and practices of that agency, as they apply to the plaintiff, should be scrutinized to determine whether they meet a constitutional standard of reasonableness. More precisely, if the procedures and practices in force at the time of the incident could not reasonably have been expected to prevent the constitutional injury, the defendants should be held negligent and thus responsible for causing the constitutional violation. The Note compares this proposal, which would place an affirmative duty on some governmental officials, with the narrower conception of negligence and its consequences for constitutional tort liability in the two Supreme Court cases that have considered section 1983 negligence claims against supervisors.

\section{The Current Approach to Supervisory Liability in Constitutional Tort Suits}

Damages for constitutional violations have only gradually become available against governmental entities. In part because of an initial premise of

violation-

(A) directed, authorized, approved, or encouraged any action by such subordinate officer or employee which resulted in such violation, or

(B) failed to act in any manner to remedy a pervasive pattern of unconstitutional or unlawful conduct engaged in by such subordinate officer or employee which, in the absence of remedial action, was likely to continue or recur in the future. . . .

S. 35, 95th Cong., 1st Sess., 123 CONG. REC. 1, 557-58 (1977). Since the decision in Monell, however, no further action has been taken on this bill, as both Monell and Owen v. Gity of Independence, 445 U.S. 622 (1980) (city cannot claim qualified immunity based on good faith of its officials) were thought to obviate the need for the bill's major provisions. See Schuck, Suing Our Servants: The Court, Congress, and the Liability of Public Officials for Damages, 1980 SUP. CT. REV. 281, 286 n.18. For an analysis of the proposed legislation, see Bell, Proposed Amendments to the Federal Tort Claims Act, 16 HARV. J. LEGIS. 1 (1979). Yet if Congress, not the Court, has the responsibility to expand liability in this area, such legislative efforts must be renewed. Cf. Fitzpatrick v. Bitzer, 427 U.S. 445 (1976) (Eleventh Amendment does not bar congressional authorization of Title VII suits against states pursuant to section 5 of Fourteenth Amendment).

9. Since public officials exercise governmental, not personal, authority, their acts carry greater weight than do those of private individuals. As Justice Brennan has observed:

A private citizen, asserting no authority other than his own, will not normally be liable in trespass if he demands, and is granted, admission to another's house. . . . But one who demands admission under a claim of federal authority stands in a far different position. . . . The mere invocation of federal power by a federal law enforcement official will normally render futile any attempt to resist an unlawful entry or arrest by resort to the local police; and a claim of authority to enter is likely to unlock the door as well.

Bivens v. Six Unknown Named Agents of the Fed. Bureau of Narcotics, 403 U.S. 388, 394 (1971) (citations omitted); see also Bertot v. School Dist. No. 1, 613 F.2d 245, 252 (10th Cir. 1979) ("Section 1983 has, at its core, a concern for fundamental fairness between a powerful government and the individual."). The standard of liability for the wrongful exercise of this unique power must reflect the difference between such acts and ordinary torts. 
sovereign immunity, ${ }^{10}$ and in part because of the strong influence of traditional tort notions, constitutional tort defendants most frequently have been individuals-governmental employees who are sued in their official capacity. At common law, an individual's responsibility for his conduct often depends upon his state of mind with respect to that conduct. Under an analysis patterned after the common law, courts readily approve constitutional tort damages against governmental officials whose intentional tortious acts are found to be under color of state law. ${ }^{11}$ The Supreme Court has adapted this framework to the bureaucratic context to determine supervisory liability. It requires that plaintiffs prove "direct responsibility"12 before supervisors are held liable for the acts of their subordinates. ${ }^{13}$

10. The origins of the sovereign immunity doctrine are obscure. Early on, the Eleventh Amendment was interpreted to bar all suits by United States citizens against any state. Hans v. Louisiana, 134 U.S. 1 (1890). The language of that provision and its legislative history, however, indicate that much less than a blanket immunity may have been intended. See C. JACOBS, THE ELEVENTH AMEND. MENT AND SOVEREIGN IMMUNITY 67-74 (1972). Defending governmental immunity in Kawananakoa v. Polyblank, 205 U.S. 349, 353 (1907), Justice Holmes cited the "logical and practical ground that there can be no legal right as against the authority that makes the law on which the right depends." Yet where constitutional claims are asserted, the right does not depend upon the government, but rather arises from the basic law that seeks to control that government. See Dellinger, Of Rights and Remedies: The Constitution as a Sword, 85 HARV. L. REV. 1532, 1556-59 (1972). For discussion and cases pertaining to the immunity of the federal government, see P. BATOR, P. MISHKIN, D. SHAPIRO, \& H. WEGHSLER, HART \& WEGHSLER'S THE FEDERAL COURTS AND THE FEDERAL SYSTEM 1339 (2d ed. 1973) ("The doctrine developed largely in dicta, reflecting evidently a general professional opinion."); id. at 1339-51.

11. See, e.g., Feemster v. Dehntjer, 661 F.2d 87 (8th Cir. 1981) (excessive force used on arrestee); Orpiano v. Johnson, 632 F.2d 1096 (4th Gir. 1980) (unprovoked attack on shackled prisoner), cert. denied, 450 U.S. 929 (1981); cf. Bogard v. Cook, 586 F.2d 399, 412 (5th Cir. 1978) (requiring that "reckless" or "grossly negligent" claims fall on "actual intent side of those terms"), cert. denied, 444 U.S. 883 (1979).

12. Rizzo v. Goode, 423 U.S. 362, 375-77 (1976). In Rizzo, a class action suit seeking equitable relief against the Mayor of Philadelphia, the Police Commissioner, and others, the Supreme Court held that absent a showing of direct responsibility, the defendant supervisors who failed to act in the face of a pattern of constitutional violations by subordinates could not be held liable for having caused those violations. Id. at 373-77. Monell v. Department of Social Servs., 436 U.S. 658 (1978), carries this notion of direct responsibility into the realm of organizational liability. In that case, the Court declared that a plaintiff must successfully challenge an official policy or custom before a governmental agency can be deemed "responsible" for or "the moving force behind" a constitutional violation. Id. at 694; see also Martinez v. California, 444 U.S. 277, 285 (1980) (death of plaintiffs' decedent at the hands of a parolee was "too remote a consequence of the parole officers' action to hold them responsible under the federal civil rights law").

13. In the lower federal courts, the scope of supervisory liability varies from case to case and from court to court. In Turpin v. Mailet, 579 F.2d 152 (2d Cir. 1978), a municipality failed to discipline or deny promotion to a city police officer after a section 1983 judgment against him; the municipality was held liable in a second suit by the same civil rights plaintiff for sanctioning the harassment of him by members of the police force in the wake of the first suit against their coworker. Turpin was vacated in light of Monell under the name City of West Haven v. Turpin, 439 U.S. 974 (1978), and was retried to a jury that again found for the plaintiff. The second judgment was overturned on appeal. Turpin v. Mailet, 619 F.2d 196 (2d Cir. 1980). Although the circuit court approved of the standard of "explicit or tacit authorization or encouragement" that had been applied by the trial court, it held that, as a matter of law, there was a failure of proof in this case. 619 F.2d at 200-01, 203; cf. Webster v. City of Houston, 689 F.2d 1220, 1225-27 (5th Gir. 1982) (city liable for police department's "policy or custom" of covertly approving officers' practice of planting guns on unarmed victims of police shootings); Garner v. Memphis Police Dep't, 600 F.2d 52 (6th Cir. 1979) (remand- 
There has been much confusion over whether negligence, a traditional basis of tort liability, can state a cause of action against supervisory defendants in a constitutional tort case. ${ }^{14}$ Negligence liability is predicated on the existence of a duty that has been breached. At common law, this duty is generally measured by the "reasonable person" standard. Yet even under common law theory, breach of this duty is deemed less culpable than an intentional wrong. ${ }^{15}$ Understandably, then, the negligence of governmental employees is not easily comprehended by many as a "fault" to be imputed to the government as a constitutional wrong. Damage claims made on this basis seem to bear out the suspicions of some judges that the constitutional damage remedy is becoming merely a form of social insurance. ${ }^{16}$ Moreover, the courts have long been reluctant to impose any tort duty whatsoever on supervisory-level governmental officials out of a concern that such a requirement would unduly interfere with the exercise of discretion inherent in their official tasks. ${ }^{17}$

ing in light of Monell to determine whether municipality's use of deadly force under Tennessee law to capture allegedly nondangerous felons fleeing from nonviolent crimes and use of hollow point bullets is "policy or custom" for which city will be held liable). But cf. Hoopes v. City of Chester, 473 F. Supp. 1214 (E.D. Pa. 1979) (complaint against city mayor failed to state cause of action because alleged custom whereby mayor controlled police department for his own gain and pleasure was not a custom for which the city could be held liable).

14. See supra note 7.

15. Although the distinguishing characteristic of the common law tort is "harm" rather than "fault," intentional invasions of interests have traditionally provided a clearer case for the imposition of liability than have unintentional departures from the normal standard of conduct. See RESTATEMENT (SECOND) OF TORTS $\S 435 B$ comment a (1965) ("[R]esponsibility for harmful consequences should be carried further in the case of one who does an intentionally wrongful act than in the case of one who is merely negligent or is not at fault."). A modern theory of tort liability predicated upon this notion is Epstein, A Theory of Strict Liability, 2 J. LEGAL. STUD. 151 (1972).

16. Cf. Monell v. Department of Social Servs., 436 U.S. 658, 693-94 (1978) (rejecting respondeat superior and policy of spreading accident costs as basis for imposing municipal liability). Regardless of the validity of this concern, there is a pressing need for firm linedrawing between constitutional torts and common law claims against governmental defendants. Between 1961 and 1979, the number of claims filed in federal court under "civil rights statutes"-primarily section 1983-rose from 296 to 24,951. Maine v. Thiboutot, 448 U.S. 1, 27 n.16 (1980) (citing 1979 DIRECTOR OF THE ADMIN. OFFICE OF THE UNITED STATES COURTS ANNUAL REPORT 6, 16-17 app.). In addition, "several thousand" Bivens actions reportedly have been brought against federal officials. See Bell, supra note 8, at 1. For expressions of judicial concern over this increase in the federal caseload, see Butz v. Economou, 438 U.S. 478, 517-30 (1978) (Rehnquist, J., concurring in part and dissenting in part); $H$. FRIENDLY, FEDERAL JURISDICTION: A GENERAL VIEW 90-100 (1973); Aldisert, Judicial Expansion of Federal Jurisdiction: A Federal Judge's Thoughts on Section 1983, Comity and The Federal Caseload, 1973 ARIZ. ST. L.J. 557.

17. The classic expression of this view is in an opinion by Judge Learned Hand:

It does indeed go without saying that an official, who is in fact guilty of using his powers to vent his spleen upon others, or for any other personal motive not connected with the public good, should not escape liability for the injuries he may so cause; and, if it were possible in practice to confine such complaints to the guilty, it would be monstrous to deny recovery. The justification for doing so is that it is impossible to know whether the claim is well founded until the case has been tried, and that to submit all officials, the innocent as well as the guilty, to the burden of a trial and to the inevitable danger of its outcome, would dampen the ardor of all but the most resolute, or the most irresponsible, in the unflinching discharge of their duties. Gregoire v. Biddle, 177 F.2d 579, 581 (2d Cir. 1949). 
Any attempt to address these issues squarely is made difficult by the fact, never directly confronted by most courts, that an allegation of negligence in an organizational setting may mean many different things: lowlevel officials may act intentionally but their ignorance of the rules may be characterized as negligent, ${ }^{18}$ or supervisors, although adequately apprised of the law, may be negligent when they direct actions based on a mistaken view of the facts. ${ }^{19}$ Official acts, regardless of the state of mind with which they are committed, may manifest an insufficiently articulated policy, ${ }^{20}$ or they may be merely the result of mechanical error. ${ }^{21}$

The Supreme Court has twice considered claims of negligence against supervisory defendants. ${ }^{22}$ Both decisions employ a traditional common law negligence analysis to limit constitutional tort liability, with the result that each adopts an overly narrow explanation of the wrong alleged and

18. Compare Russell v. Bodner, 489 F.2d 280, 281 (3d Cir. 1973) (reversing dismissal of complaint where guard confiscated seven packs of cigarettes in order to demonstrate that inmate had no remedy-"I'll prove it to you") with Madison v. Manter, 441 F.2d 537 (1st Cir. 1971) (affirming dismissal of complaint where police officers charged with negligent failure to obtain search warrant).

19. But see Johnson v. Shaw, 609 F.2d 124 (5th Cir. 1980) (absent specific knowledge, Department of Corrections Director who promulgated lawful discharge procedures not liable to prisoner held beyond correct date).

20. Compare Bogard v. Cook, 586 F.2d 399 (5th Cir. 1978) (no liability for negligent administration of prison resulting in physical abuse of inmates), cert. denied, 444 U.S. 883 (1979) with Carter v. Estelle, 519 F.2d 1136 (5th Cir. 1975) (cause of action lies against supervisors for negligence of prison guards in allowing prisoner property to be exposed to theft).

21. Compare McCray v. Maryland, 456 F.2d 1 (4th Cir. 1972) (negligent failure of court clerk to mail prisoner's application for post-conviction relief states cause of action under section 1983) with Jenkins v. Meyers, 338 F. Supp. 383, 389-90 (N.D. Ill. 1972) (no cause of action stated where failure to mail prisoner's trial transcript to attorney was not a "conscious" act), afr'd mem., 481 F.2d 1406 (7th Cir. 1973).

22. The Supreme Court also granted certiorari on the question of negligence liability in a third case, Procunier v. Navarette, 434 U.S. 555 (1978), which involved the alleged wrongful interference with a prison inmate's outgoing mail. Navarette did not reach the negligence question, however, as the case was decided on the threshold issue of qualified immunity. The Court held that as the legal right asserted was not "clearly established" at the time of the events in question, the defendant prison officials could not reasonably have been expected to have knowledge of it or to conform their behavior to respect its existence. Id. at 565 .

Navarette does not receive detailed treatment in this Note because the basis for criticizing the Court's holding-the indeterminate meaning of the "clearly established" requirement-relates only indirectly to the theory of negligence that will be advanced here. It should be observed, however, that the justification for the "clearly established" test set out in Navarette-that it is unfair to hold a defendant to legal requirements that he could not reasonably have predicted-is a much stronger argument when advanced to explain the legal responsibilities of a front-line governmental employee than it is to explain why supervisory or agency defendants-the plaintiff in Navarette had sued the entire prison hierarchy-should be excused from their obligation to keep current with emerging constitutional doctrine. At the very least it should be acknowledged that different public officials are responsible for different levels of legal knowledge.

Inasmuch as this criticism of Navarette illustrates the inaptness of notions of individual culpability where governmental obligations are involved, it supports this Note's thesis. For a more recent formulation of the clearly established test, see Harlow v. Fitzgerald, 102 S. Ct. 2727, 2737-39 (1982). Criticism of earlier versions of this test can be found in Kattan, Knocking on Wood: Some Thoughts on the Immunities of State Officials to Civil Rights Damage Actions, 30 VAND. L. REV. 941, 9781003 (1977); Developments in the Law: Section 1983 and Federalism, 90 HARV. L. REV. 1135, 121516 (1977). 
reaches an unduly restrictive conclusion concerning the appropriate scope of constitutional tort liability.

\section{A. Statutory Construction: Baker v. McCollan and the Causation Clause of Section 1983}

Facial examination of section 1983 has led the Supreme Court to declare that a constitutional tort claim has three necessary elements: The plaintiff must assert "rights, privileges, or immunities secured by the Constitution or laws . . ."; the defendant must be acting "under color" of state law; and the defendant's conduct must "cause" plaintiff "to be subjected" to the deprivation of his rights. ${ }^{23}$ To aid it in determining liability within these broad statutory boundaries, the Court has implicitly adopted the common law practice of characterizing the action alleged to have caused the harm in narrow, personal terms. As a result, in constitutional tort cases in which the individual responsible for an action is not easily identifiable, liability analysis may be governed more by pragmatism than by principle. Claims alleging negligence in an institutional setting fall squarely within this category and thus receive less than certain protection under current section 1983 analysis.

In Baker v. McCollan, ${ }^{24}$ the plaintiff alleged that he had been deprived of his Fourteenth Amendment due process rights when he was detained for a week under a valid warrant for the arrest of his brother, who had used plaintiff's name as an alias. The Supreme Court acknowledged that even one detained pursuant to a valid warrant is entitled to due process protection. It concluded, however, that the sheriff, named as defendant in Baker, had not caused plaintiff to be deprived of any constitutional rights. As a result, the sheriff was not responsible for the plaintiff's erroneous detention. ${ }^{25}$

In absolving the sheriff of liability, the Court focused on the issue of causation, which is both a tort element and a statutory requirement under section 1983. The Court confined its scrutiny to the extent of the sheriff's active, personal contribution to plaintiff's wrongful confinement: obtaining an arrest warrant. The Court declared that since the warrant was facially valid, the Fourth Amendment requirement of probable cause as a precondition to significant pretrial detention had been satisfied. Although noting that after a "lapse of a certain amount of time" the plaintiff might have invoked a right to bail and to a speedy trial, the Court declared that these concerns did not arise in Baker, in part because of the short duration of

23. See Parratt v. Taylor, 451 U.S. 527,535 (1981).

24. 443 U.S. 137 (1979).

25. Id. at $142-44$. 
the detention and in part because they would involve acts by public officials-"committing magistrates and judicial officers"-other than the county sheriff. ${ }^{28}$

If the incident in Baker is to be judged as a series of discrete acts by individuals, it is clear that those whose personal and affirmative acts caused the plaintiff's wrongful confinement were the sheriff's deputies. ${ }^{27}$ Yet from an organizational standpoint, the strict dichotomy between the acts of the deputies and those of the sheriff, which is necessary to support Baker's liability analysis, is inaccurate. As the official in charge, a sheriff is responsible for the procedures employed by his subordinates in carrying out the office's business of arresting and imprisoning criminal suspects. Looking only as far as the warrant the sheriff procured, the Baker Court did not further consider the extent to which he was responsible for acts carried out under his authority. ${ }^{20}$

In attributing the acts of his deputies to the sheriff, the plaintiff in Baker challenged the sheriff in his role as supervisor and administrator. ${ }^{30}$

26. Id. at 145 .

27. Over protests that he was the wrong man, plaintiff was taken into custody in Dallas after a routine warrant check revealed that he was wanted in Potter County, Texas. Telephone confirmation of the information on plaintiff's driver's license was given by the Potter County deputies based upon the driver's license in their files. Plaintiff alleged that the altered driver's license in their file gave the deputies reason to believe that the wanted man was using his name as an alias. Id. at 150 . Plaintiff remained in the Dallas jail for five days until the deputies arrived to retrieve him. Despite his repeated protests, plaintiff's files were not checked for another three days until the Potter County sheriff, returning from vacation, examined the file material and realized the error. Id. at 150-51.

28. Many courts have recognized that the office of the sheriff is an institution, not an individual. In Bryan v. Jones, 530 F.2d 1210, 1216 (5th Cir.) (en banc), cert. denied, 429 U.S. 865 (1976), the Fifth Circuit observed: "[The sheriff] must have helpers and once he has established-which he must-a system which eliminates the hazard of mistakes to the maximum reasonable extent, he must depend upon the helpers. The law must in some way take that into account."

In his institutional role, a sheriff is liable for acts other than those affirmatively taken by him as an individual. See, e.g., Bryan v. Jones, 530 F.2d at 1215 (sheriff not generally liable for keeping one prisoner in jail based on erroneous grand jury report but if "he negligently establishes a record keeping system in which errors of this kind are likely, he will be held liable"); Withers v. Levine, 615 F.2d 158, 162 (4th Cir.) ("Given the pervasive and unreasonable risk of harm, negligence by prison officials in performance of their duty of care is a violation of the constitutional right and actionable under section 1983."), cert. denied, 449 U.S. 849 (1980); Roberts v. Williams, 456 F.2d 819 (5th Cir.) (affirming liability of prison warden for negligent choice and training of trusty guard, previously convicted of assault with intent to kill, who shot inmate-plaintifi), cert. denied, 404 U.S. 866 (1972).

29. Rejecting the reasoning of the court of appeals below, which had declared that the sheriff could be held liable for his deputies' acts, the Supreme Court in Baker likened such liability to an erroneous constitutional guarantee that only the guilty will be arrested. Baker v. McCollan, 443 U.S. 137, 145 (1979); cf. Rizzo v. Goode, 423 U.S. 362 (1976) (mayor and police commissioner have no constitutional duty to eliminate police misconduct). Yet while under no absolute obligation to prevent wrongful arrests, officials who train and supervise arresting officers are responsible for promoting the lawful execution of front line responsibilities. See, e.g., Turpin v. Mailet, 619 F.2d 196, 200-02 (2d Cir.) (city officials can be held liable for policy of harassment by police officers, though in present case plaintiff's evidence was insufficient), cert. denied, 449 U.S. 1016 (1980); Carter v. Carlson, 447 F.2d 358, 364-65 (D.C. Cir. 1971) (suit can be maintained against police officials responsible for training and supervision of police officers), rev'd on other grounds sub nom. District of Columbia v. Carter, 409 U.S. 418 (1973).

30. Although the plaintiff had attempted to sue the deputies as well, claims against them were 
The court of appeals below held him liable in this position, stating that the sheriff had negligently failed to institute procedures to insure that the person arrested and detained was actually the one sought. ${ }^{31}$ The Supreme Court's more limited understanding of the sheriff's authority led it to mischaracterize the lower court's analysis as having erroneously placed an affirmative common law duty on the sheriff "to investigate independently every claim of innocence . . . [and] perform an error-free investigation of such a claim."'s2 Yet, framed by the court of appeals as an issue of negligence, the question squarely presented to the Supreme Court in Baker was whether the sheriff was under a duty in his supervisory capacity to promulgate identification and verification procedures to prevent mistakes such as the one in this case. ${ }^{33}$ In vindicating the sheriff as an individual by limiting his duty to acts directly caused by him in that capacity, Baker failed to address the important question of organizational responsibility. ${ }^{34}$

\section{B. Constitutional Interpretation: Parratt v. Taylor and the Adequacy of State Remedies Under the Due Process Clause}

In Baker, the Court's treatment of the alleged violation as a series of particularized, individual acts permitted it to analyze causation, as well as the analytically prior question of duty raised by the negligence claim, in traditional common law terms. This approach was not required by section 1983, and led the Court to resolve the issue of constitutional tort liability by means of a largely common law analysis.

Like Baker, Parratt v. Taylor ${ }^{35}$ treated the allegation of negligent conduct as a challenge to the actions of individuals. In Parratt, however, this characterization did not affect the Court's analysis of the tort issues of causation and duty but instead led to an unneccessarily restrictive interpretation of the constitutional due process right allegedly violated. ${ }^{38}$ The

dismissed with prejudice. Only the summary judgment in favor of the sheriff was appealed. McCollan v. Tate, 575 F.2d 509, 511 (5th Cir. 1978), rev'd sub nom. Baker v. McCollan, 443 U.S. 137 (1979).

31. McCollan v. Tate, 575 F.2d at 513.

32. Baker v. McCollan, 443 U.S. 137, 146 (1979).

33. The sheriff himself testified that it was standard practice in most sheriff's departments of that size to send identifying material to the police in the city where the arrest was made. This practice was not followed in this case. McCollan v. Tate, 575 F.2d 509, 513 (5th Cir. 1978), rev'd sub nom. Baker v. McCollan, 443 U.S. 137 (1979).

34. See Dewell v. Lawson, 489 F.2d 877, 881-82 (10th Cir. 1974) (police chief failed to establish proper identification procedures; diabetic plaintiff carrying medical identification jailed for four days as common drunk); Beverly v. Morris, 470 F.2d 1356, 1357 (5th Cir. 1972) (police chief failed to provide any training for auxillary police officer who blackjacked plaintiff).

35. 451 U.S. 527 (1981).

36. Several Supreme Court decisions have imposed a common law-like requirement of intent so as to narrow the protection afforded by some constitutional rights. Personnel Adm'r v. Feeney, 442 U.S. 256, 276 (1979) (equal protection violation requires that defendant have discriminatory purpose or intent); Village of Arlington Heights v. Metropolitan Hous. Dev. Corp., 429 U.S. 252, 265 (1977) (same); sce Estelle v. Gamble, 429 U.S. 97, 106 (1976) (Eighth Amendment requires showing of 
impact of employing this common law approach is apparent in Parratt's conclusion that common law tort remedies satisfy constitutional due process requirements in cases where negligence is alleged.

The dispute in Parratt was between a state prisoner and prison authorities over the disappearance of prepaid hobby materials that the plaintiff had ordered through the mail. Arriving while the plaintiff was in segregation, the package was signed for by two employees of the prison hobby center - a departure from the established regulations-and subsequently disappeared ${ }^{37}$ After getting no satisfactory response through the prison's internal grievance procedure, ${ }^{\mathbf{3 8}}$ the plaintiff filed suit against the prison warden and the hobby manager, alleging that their negligent conduct had deprived him of property without due process of law. Although the Court found that the conduct complained of in Parratt was both "under color of state law" and a "deprivation of property," it nonetheless concluded that no Fourteenth Amendment violation had taken place because the deprivation occurred with due process of law..$^{39}$

The analysis in Parratt focused on the timing of a hearing. The Court noted that the plaintiff had neither challenged the prison mail regulations as inadequate nor contended that a formal predeprivation hearing should have been provided. Observing that the charge against the prison officials was negligence, the Court concluded that a prior hearing would have been

"deliberate indifference"). Parratt, however, is the first Supreme Court case to consider the relationship between negligence and the particular constitutional right asserted.

37. 451 U.S. at 530.

38. Id. at 556 .

39. Id. at 536-37. In reaching this conclusion, Parratt relied upon Bonner v. Coughlin, 517 F.2d 1311 (7th Gir. 1975), modified en banc, 545 F.2d 565 (1976), cert. denied, 435 U.S. 932 (1978), in which Judge (later Justice) Stevens advanced the novel proposition that where subordinate officials depart from established state procedures "the state action is not necessarily complete." Parratt, 451 U.S. at 542 (quoting Bonner v. Coughlin, 517 F.2d at 1319). Maintaining that such acts are still "under color of law," Bonner went on to find that the existence of a state law remedy "avoids the conclusion" that a due process violation has occurred. 517 F.2d at 1319.

The flaw in this analysis is readily apparent. As Monroe v. Pape, 365 U.S. 167, 184 (1961), established, exercise of authority by officials in a manner that deviates from established procedures is clearly within the definition of state action for the purpose of identifying constitutional deprivations under section 1983. If an act concededly under color of law becomes, by virtue of the label "incomplete state action," not a constitutional deprivation, then a federal court has no authority to inquire into the constitutional adequacy of any state law remedies provided.

Justice Powell, concurring in Parratt, criticized the majority for passing over the threshold question of whether a negligent act can be a constitutional violation. 451 U.S. at 547 (Powell, J., concurring). Observing that the majority's solution turns the Fourteenth Amendment into a "font of tort law" in cases where common law negligence is alleged, Powell offered a more logical solution to the question as posed. He would limit the scope of the due process clause, like the equal protection clause, to intentional violations, thereby eliminating Supreme Court review of the adequacy of state law remedies. Id. at 548; accord Bonner v. Coughlin, 545 F.2d 565 (7th Cir. 1976) (en banc) (modifying earlier three-judge opinion) (negligent deprivation of property by prison guards is not constitutional violation), cert. denied, 435 U.S. 932 (1978).

This Note rejects the framework of common law negligence imposed on the defendants' actions in Parratt. The solution advanced here differentiates between claims meriting federal constitutional remedies and those requiring state remedies on a different basis. 
impossible because negligence cannot be predicted in advance. ${ }^{10}$ The Court ruled that an existing state compensation scheme, which included a hearing for those injured by its officials, provided all the process constitutionally necessary in this case. ${ }^{41}$

Although it is facially appealing, closer inspection reveals that Parratt's constitutional interpretation is flawed because the opinion mischaracterized the allegedly wrongful conduct before it. The Court was unsuccessful in its attempt to analogize the situation in Parratt to due process cases in which postdeprivation remedies were held to be adequate due process. ${ }^{42}$ Parratt is not a case like Mitchell v. W.T. Grant Co., ${ }^{43}$ which involved the rights of a debtor plaintiff to continued possession of his property after a creditor obtains an ex parte writ of sequestration on the property. The plaintiff in Parratt was clearly entitled to the hobby material, having paid when he ordered it through the mail. Moreover, in Mitchell, the protection provided by the impartial judicial procedures through which the writ was obtained, and the provision of a postdeprivation court hearing to determine the validity of the initial act, were important factors in the decision that no due process violation had occurred. 14 In Parratt, by contrast, the Court did not examine the precise nature of the pre- and post-loss processes. In particular, the Court ignored the fact that no post hoc remedy was provided by the prison as a review of the earlier acts of its officials. Rather, the remedial process approved was a general state compensation scheme, the existence of which was not communicated to plaintiff until well after he sued.

Parratt is also unlike the public health and safety cases cited by the Court. For example, in North American Cold Storage Co. v. Gity of Chicago $^{45}$ the plaintiff's interest in prior procedural safeguards was deemed to be outweighed by the importance and urgency of a legitimate state interest. In such situations, exigent circumstances permit immediate confiscation; the plaintiff may then dispute the confiscation in a subsequent pro-

40. Parratt, 451 U.S. at 543-44. The Court's analysis of this point is strained. Justice Rehnquist, writing for the majority, notes that although the negligence claim was directed against the prison warden and hobby manager, the record contained no evidence that they personally engaged in any injurious acts that could be described as unintentional conduct. Id. at 537 n.3. Yet rather than exploring the dimensions of the negligence claim against these officials, the Court inexplicably asserted that the alleged negligence referred to unintentional acts, which were not amenable to official control. Id. at 541. Parratt's due process analysis then proceeds from this ill-founded assumption.

41. Id. at 543 .

42. Id. at $538-41$.

43. 416 U.S. 600 (1974).

44. Id. at 616-18.

45. 211 U.S. 306 (1908) (seizure of food unft for consumption). In Parratt, 451 U.S. at 538-39, the Court also cited: Ewing v. Mytinger \& Casselberry, Inc., 339 U.S. 594 (1950) (seizure of misbranded articles in commerce); Fahey v. Mallonee, 332 U.S. 245 (1947) (substantial questions about competence of bank management justify appointment of conservator); Corn Exchange Bank v. Coler, 280 U.S. 218 (1930) (seizure of assets of absconding husband). 
ceeding. When a governmental official is negligent, however, no state interest comparable to that justifying the seizure of spoiled goods outweighs the plaintiff's interest in prior process and warrants limiting the scope of his due process protection to a subsequent hearing.

The Parratt Court's unrealistically narrow understanding of due process as requiring a choice between a predeprivation and a postdeprivation hearing can be traced, once again, to its treatment of the alleged violation as an act by individual officials that violates the common law standard of negligence. The Court distinguished between intentional and negligent acts by governmental employees, declaring that the "random" and "unauthorized" nature of the latter makes it impossible to provide prior process. ${ }^{16}$ Such a dichotomy is not sufficiently precise. It is true that where an organization has intentionally adopted a policy, the constitutional need for a prior hearing may be apparent. ${ }^{47}$ However, many acts of subordinate officials, both intentional and negligent, that deviate from stated policies cannot be thus anticipated..$^{8}$ On the other hand, many such acts and their effects can be forestalled by organizational procedures designed to ensure adherence to stated policy. In sum, to acknowledge that there is a difference between the negligence of individuals and negligence at the level of organizational practice and that this difference is comparable to the distinction between intentional acts and intentionally adopted policy is to allow that there are numerous organizational opportunities to control deviations from stated policy.

From this perspective, it becomes clear that the postdeprivation compensation scheme sanctioned by the Court was not a procedural safeguard afforded to plaintiff but was merely a remedy for the absence or failure of any such safeguards. Yet Monroe v. Pape held over twenty years ago that the existence of a state tort remedy for a constitutional wrong does not foreclose plaintiff's choice of a federal forum and federal remedy under section 1983. ${ }^{49}$ Because of its adherence to common law distinctions inap-

46. 451 U.S. at $540-41$.

47. In Parratt, 451 U.S. at 539, the Court gave a number of examples of this type of state action: Fuentes v. Shevin, 407 U.S. 67 (1972) (state replevin proceedings); Goldberg v. Kelly, 397 U.S. 254 (1970) (termination of welfare benefits); Sniadach v. Family Fin. Corp., 395 U.S. 337 (1969) (garnishment of wages).

48. Indeed, the explanation given in Parratt for not requiring prior process-that is, the lack of opportunity for official control of negligent acts-has also been used to excuse upper level officials from liability where their subordinates engage in unusual and unpredictable intentional conduct. See, e.g., Wilson v. Beebe, 612 F.2d 275 (6th Cir. 1980) (no liability for failure to train and supervise where plaintiff did not show direct responsibility of supervisors for police officer shooting of plaintiff while trying to handcuff him with cocked revolver in hand); cf. Payne v. Government of Dist. of Columbia, 559 F.2d 809, 823 (D.C. Cir. 1977) (per curiam) (Tamm, J., concurring in remand) (supervisory liability unlikely where officer who fired at plaintiffs was off duty, out of uniform, investigating possible theft from own car; plaintiffs did not discover his occupation until after reporting incident; but noting that city had not yet denied that police officer acted as its agent).

49. Monroe v. Pape, 365 U.S. 167, 183 (1961). 
plicable in the constitutional tort setting, Parratt v. Taylor appears to have effectively reversed Monroe for a large class of due process claims in which the wrongful actions of lower-level officials, whether negligent or intentional, are not sanctioned by official policy. ${ }^{\text {Bo }}$

Incorporating common law negligence assumptions into its Fourteenth Amendment analysis may have enabled the Supreme Court in Parratt to channel away from federal courts a class of cases that it believed merited only state law remedies. ${ }^{\text {s1 }}$ Yet analysis of both Baker v. McCollan and Parratt v. Taylor demonstrates that the integration of common law negligence with constitutional tort analysis has only blurred the distinction between constitutional and common law tort claims against the state. The conclusion in Parratt is the most striking example of the extent to which the unscrutinized adoption of common law concepts has jeopardized the independence of the constitutional tort action. If there is to be a role for negligence in constitutional tort theory, it must be a negligence deduced from constitutional, not common law, tort principles.

\section{Causation, Constitutional Duty, and Unauthorized Conduct}

The Supreme Court's interpretation of the requirements of a constitutional tort as set out in section 1983 is incomplete because the Court fails to deal explicitly with the issue of responsibility, which needs to be addressed before determining whether the tort and statutory requirement of

50. The propriety of the outcome in Parratt is also cast in doubt by the Supreme Court's more recent decision in Patsy v. Board of Regents, 102 S. Ct. 2557 (1982). In that case, which involved the validity of a federal judicial requirement that plaintiff exhaust state administrative remedies before pursuing a sex discrimination claim under section 1983, the Court declared that apart from the explicit exception carved out in 42 U.S.C. $\$ 1997$ (c) for prison inmate petitions, a general state administrative exhaustion requirement under section 1983 could not be supported by legislative history or policy. Patsy, 102 S. Ct. at 2561-66. It is difficult to understand how Parratt's outright and total substitution of a state administrative for a federal court remedy under section 1983 can be justified when deferral of federal suit through a requirement of prior exhaustion of state administrative process is not.

51. Cf. Ingraham v. Wright, 430 U.S. 651 (1977) (state provided safeguards sufficient to protect against risk of constitutionally wrongful punishment); Paul v. Davis, 424 U.S. 693, 701 (1976) (reputation is right protected only by state law, not a constitutional liberty interest).

Although it was passed too late to influence the litigation in the Parratt case, the Civil Rights of Institutionalized Persons Act, 42 U.S.C. \$1997 (Supp. V 1981) sets out the circumstances under which a prison inmate should be required to utilize state administrative remedies such as those approved in Parratt. Section 1997(e) empowers a federal district court to delay for 90 days a section 1983 action brought by a prison inmate "in order to require exhaustion of such plain, speedy, and effective administrative remedies as are available." The process contemplated by this provison dovetails with the one proposed in this Note: The 90-day delay permitted by the statute should encourage prison administrators to respond to inmate complaints by prompt administrative remedies-a course never pursued by the defendants in Parratt. See Patsy v. Board of Regents, 102 S. Ct. 2557, 2566 (1982) (Congress provided for deferral of federal jurisdiction over $\S 1983$ claims by prison inmates in order to give prisons incentive to develop adequate grievance procedures). Indeed, there might have been no due process violation in Parratt had plaintiff been directed to such a scheme upon discovery of the loss of his property. In those cases where administrative compensatory measures do not erase the wrong, the statute leaves an inmate free to pursue his federal constitutional remedies in federal court. 
causation was met. ${ }^{\mathbf{5 2}}$ In the two cases discussed above, the Court focused upon whether the supervisory defendants had caused the harm of which the plaintiff complained; in neither case had the plaintiff pointed to a specific action of the defendants that could be deemed to have set in motion the events leading to the injury actually inflicted by other subordinate officials. In Baker, the Court interpreted the tort requirement of causation, and by extension the cause clause of section 1983, to include only the individual affirmative acts of the sheriff. Parratt, on the other hand, focused upon the distinction between effects caused by individual acts and those that result from established procedures. In that case, the Court interpreted the due process clause to mean that if an officially adopted procedure did not directly cause the deprivation and an after-the-fact state remedy was provided to compensate for the injury, the plaintiff did not suffer Fourteenth Amendment harm. The issue obscured in both Baker and Parratt is whether the supervisory defendants should have been held responsible for the harm directly caused by their subordinates. Both common law and constitutional tort theory recognize that liability may be premised upon intentional conduct; in alleging negligence, the plaintiffs in these two cases were clearly pressing a second basis of supervisory liability, the breach of a duty toward them. As a matter of constitutional tort law, such a duty should have been acknowledged.

\section{A. Section 1983: Constitutional Duty and a Standard of Reasonable Conduct}

At common law, social policy sometimes requires that an affirmative duty be placed upon one of the parties to a special relationship. ${ }^{63}$ As a matter of constitutional tort policy, the relationship between the government and its citizens warrants the imposition of a special duty upon public officials. ${ }^{54}$ The Bill of Rights is a list of limitations on what govern-

52. The Supreme Court does not always identify causation as a discrete constitutional tort requirement, a fact that undoubtedly contributes to the lack of attention paid to the issue of responsibility. Nonetheless some lower court decisions have recognized that the language of section 1983 requires an inquiry into cause that is unlike common law causal analysis. See Johnson v. Duffy, 588 F.2d 740, 743 (9th Cir. 1978); Sims v. Adams, 537 F.2d 829, 831 (5th Cir. 1976); Haygood v. Younger, 527 F. Supp. 808, 816-18 (E.D. Cal. 1981).

53. The first appearances of liability for nonfeasance at common law involved persons engaged in "public" callings such as common carriers, innkeepers, and public warehousemen. By holding themselves out to the public, these persons were regarded as having undertaken a duty to give service, for the breach of which they were liable. W. PROSSER, HANDBOOK OF THE LAW OF TORTS $\S 56$, at 339 (4th ed. 1971); RESTATEMENT (SECOND) OF TORTS § 314A (1964). Moral and social obligation underlie the civil duty to rescue in Good Samaritan statutes. See VT. STAT. ANN. tit. 12, § 519 (1973); see also Tarasoff v. Regents of the Univ. of Cal., 17 Cal. 3d 425, 551 P.2d 334, 131 Cal. Rptr. 14 (1976) (special relationship between therapists and dangerous person justifies imposition of duty to control, or warn victim of, impending harmful conduct).

54. None of the few commentators who has considered this concept explicitly has pursued the line of reasoning or proposed the uniform, overarching duty urged here. Professor Nahmod asserts that 
ment can do to its citizens while pursuing its ends. These limitations, which precede all legal constraints that the government places upon itself, embody the most fundamental obligations of government. Each of these limitations, while usually viewed from the citizen's perspective as a constitutional right, also gives rise to a concomitant governmental duty not to violate that right in the pursuit of other ends. The breach of such a constitutional duty by governmental officials can be understood as the basis for the constitutional tort action.

The government should be deemed to have fulfilled its constitutional duty when it conducts itself in a manner that is reasonable with respect to citizens' rights. Unlike good faith, reasonable belief, and various other state-of-mind standards that are presently employed as limitations on liability in constitutional tort suits, reasonable conduct is an essentially objective standard, focusing upon observable governmental activity. ${ }^{.55}$ Just as the common law may impose an affirmative duty to act where there is a special relationship between the plaintiff and the defendant, reasonable conduct in the context of a constitutional claim may involve an affirmative obligation to prevent injury, as well as a negative duty to refrain from injurious conduct. In light of this dual nature, constitutional duty is a concept easily adapted to the role differentiation of a bureaucracy, the frequent setting for constitutional violations.

Conceptually the government is the inescapable defendant in a constitutional tort suit; only the government can abridge constitutional rights. In contemporary society, most of the business of government is conducted through public agencies that employ a plethora of bureaucratic processes. ${ }^{58}$ Front-line public employees are in constant, obligatory contact with public "clients." Because of the unique, coercive power associated with their public office, the actions of these officials carry a comparatively

constitutional duty under section 1983 varies according to the Supreme Court's constitutional interpretation and perception of federal policy. Nahmod, Section 1983 and the "Background" of Tort Liability, 50 IND. L.J. 5, 22-25 (1974). Professor Paul Cox is doubtful that the Constitution provides tort liability concepts and proposes as an alternative to Nahmod's constitutional duty a statutory duty under section 1983, the application of which will lead to a new body of judicially created federal common law. Cox, Constitutional Duty and Section 1983: A Response, 15 VAL. U.L. REV. 453, 46365 (1981). Although it offers no theory to explain the conceptual basis of duty, a recent article by Professor Eaton calls upon courts to recognize the distinction between issues of duty and those of causation in constitutional tort suits and to analyze each in its own terms. Eaton, Causation in Constitutional Torts, 67 IOWA L. REV. 443, 479-80 (1982).

55. See Bonner v. Coughlin, 545 F.2d 565, 572 (7th Cir. 1976) (Swygert, J., dissenting) ("Whether the presence of the state is great enough to justify the sanctions of section 1983 must be decided by how much of the conduct of the state was in fact related to the plaintif's injury rather than by whether the state intended that conduct."), cert. denied, 435 U.S. 932 (1978); see also Estelle v. Gamble, 429 U.S. 97, 109 (1976) (Stevens, J., dissenting) (subjective motivations of individual officials are irrelevant to violation of constitutional standard of care).

56. A very thorough treatment of the bureaucratic character of government is undertaken in Schuck, supra note 8 , at 292-315. 
greater risk of harm than do private actions. At the same time, these offcials are often not responsible for the decisions they execute, and the responsibility and rationale behind their acts may therefore be difficult to locate.

Confronted with the necessary exercise of governmental authority by individual employees at the bottom of the hierarchy, courts have resisted imposing liability upon lower-level employees for the violation of constitutional standards that such employees cannot reasonably have been expected to know. ${ }^{\text {bz }}$ Similarly, upper-level officials are absolved of liability for the unauthorized acts of their subordinates. ${ }^{68}$ Yet too restrictive a view of the relationship between the upper and lower levels of the government hierarchy permits wrongs correctly attributed to the government to go unremedied. Thus, although the federal courts are understandably reluctant to scrutinize the daily exercise of administrative authority, ${ }^{80}$ their constitutional and statutory obligations require them to examine the allocation of this authority so that they may take action where governmental conduct transgresses constitutional bounds.

In those cases where the conduct challenged by the plaintiff flows from public agencies, courts must be alert to the nuances associated with the exercise of authority "under color of state law." In particular, liability determinations must be responsive to the gap between authority and execution in bureaucratic decisionmaking. ${ }^{60}$ For this reason, the constitu-

57. Cf. Pierson v. Ray, 386 U.S. 547 (1967) (police officers acting in good faith and with probable cause can claim immunity to constitutional tort suit); Foster v. Zeeko, 540 F.2d 1310, 1315 (7th Cir. 1976) (good faith is sound policy umbrella under which police should be permitted to operate). Another court has observed that absent a good faith defense police would be required "to respond in damages every time they miscalculated in regard to what a court of last resort would determine constituted an invasion of constitutional rights, even where, as here, a trial judge-more learned in the law than a police officer-held that no such violation occurred." Bowens v. Knazze, 237 F. Supp. 826, 829 (N.D. Ill. 1965).

58. See, e.g., Hays v. Jefferson County, 668 F.2d 869, 874 (6th Cir.) (supervisor liable for police misconduct only where complete failure to train police force made future misconduct inevitable), cert. denied, 103 S. Ct. 75 (1982); Adams v. Pate, 445 F.2d 105, 107 (7th Cir. 1971) (inmate who alleged he was beaten by inmate-nurse on orders of prison guards did not state cause of action against warden). For commentary on the tension between deterring constitutional violations by governmental officials and protecting official discretion, see Freed, Executive Official Immunity for Constitutional Violations: An Analysis and a Critique, 72 Nw. U.L. REV. 526 (1977); Kattan, supra note 22, at 9781002; Newman, Suing the Lawbreakers: Proposals to Strengthen the Section 1983 Damage Remedy for Law Enforcer's Misconduct, 87 YALE L.J. 447 (1978); Theis, Official Immunity and the Civil Rights Act, 38 LA. L. REV. 281, 307-09 (1978).

59. Compare Baker v. McCollan, 443 U.S. 137, 156 (1979) (Stevens, J., dissenting) (finding constitutional violation, but declining to define standards to govern law enforcement) with Procunier v. Martinez, 416 U.S. 396, 404-05 (1974) (though courts are ill-equipped to handle problems of prison administration, they must take cognizance of valid constitutional claims occurring in prisons).

60. Acknowledgement of this gap exposes the error of the conventional view that respondeat superior is strictly a public policy device by which the sins of the servant-and their costs-are visited upon the blameless master. The traditional view is represented in Holmes, Agency, 4 HARV. L. REV. 345 (1891); see also Jennings v. Davis, 476 F.2d 1271, 1274-75 (8th Cir. 1975) (describing modern rationale for rule as deliberate allocation of the risk of governmental activity). As supervisory respon- 
tional duty of reasonableness is a more expansive concept in the bureaucratic context than when applied to individuals. ${ }^{61}$ Where an official is responsible solely for his own activity, a negative duty to refrain from certain conduct is usually sufficient to fulfill his constitutional obligation. Certainly in the past, when governmental structures were less bureaucratic, an official who abstained from actively inflicting harm would be likely to avoid violating constitutional rights. Today, however, as bureaucratic government plays an increasingly active social role, respect for constitutional rights can be fulfilled only through the additional imposition upon some supervisory officials of an affirmative duty of care. In other words, supervisors should be obligated to create and administer a structure that is designed to prevent subordinates from violating constitutional rights, and to promote governmental action that, regardless of its substantive ends, reasonably respects constitutional rights. Absent such behavior, their conduct should be deemed unreasonable, or negligent.

\section{B. Implications of Bureaucratic Government Action for the Due Process Clause}

To recognize that governmental action is primarily bureaucratic action has special implications for the due process clause. The Supreme Court has said: "Once it is determined that due process applies, the question remains what process is due." cates that governmental process is often more complicated and subtle than present theory recognizes, the standard for what process is due must be readjusted accordingly.

sibility is described here, it is not inconsistent with the view expressed in Monell v. Department of Social Servs., 436 U.S. 658, 693-94 (1978), that vicarious liability cannot be imposed on governing bodies solely on the basis of the existence of an employer-employee relationship with the tortfeasor. Nor does it contradict the requirement set out in Rizzo v. Goode, 423 U.S. 362, 375-76 (1976), that there must be a showing of "direct responsibility" for the constitutional violation to hold supervisors liable for actions of their subordinates.

61. Correspondingly, the courts must employ a concept of causation that is broader than the one that presently underlies much supervisory liability analysis. Compare Maclin v. Paulson, 627 F.2d 83, 86 (7th Cir. 1980) (complaint against police chief adequate because alleges he ordered or personally participated in beating, and is not based on respondeat superior) and Hampton v. Holmesburg Prison Officials, 546 F.2d 1077, 1082 (3d Cir. 1976) ("[T]here is not the slightest evidence showing that the warden had actual knowledge of the unanswered request for medical attention or that he acquiesced or participated in any denial.") and Adams v. Pate, 445 F.2d 105, 107 (7th Gir. 1971) (no overt acts by warden or evidence that he directed infractions) and Madison v. Gerstein, 440 F.2d 338, 342 (5th Cir. 1971) (no liability where sheriff had no personal knowledge of and did not direct deputy's acts) with Withers v. Levine, 615 F.2d 158 (4th Cir.) (prison officials' duty of care requires them to devise procedures to provide inmates with reasonable protection against sexual assault), cert. denied, 449 U.S. 849 (1980) and Carter v. Estelle, 519 F.2d 1136 (5th Cir. 1975) (prison officials vicariously liable for wrongful confiscation of inmate property by guards). See also Carter v. Carlson, 447 F.2d 358, 366 (D.C. Cir. 1971), rev'd on other grounds sub nom. District of Columbia v. Carter, 409 U.S. 418 (1973) ("When a tort is made possible only through the abuse of power granted by the government, then the government should be held accountable for the abuse, whether it is negligent or intentional in character.").

62. Morrissey v. Brewer, 408 U.S. 471, 481 (1972). 
In both Baker and Parratt, which involve due process claims, the Court's narrow vision of governmental action affected its interpretation of what governmental process was constitutionally required by the Fourteenth Amendment. The essence of the holding in Baker is that subsequent procedures safeguarding other constitutional rights-such as the rights to bail and to a speedy trial-would cure any constitutional defects that might survive the Fourth Amendment process provided by the sheriff. Parratt goes even further by holding subsequent state common law procedures to be an adequate cure for allegedly defective constitutional process.

Both of these decisions elevate form-or, more precisely, procedure-over substance. Taken to their logical conclusion, they stand for the proposition that governmental officials may freely violate civil rights through unofficial practices-as long as formal corrective process is later provided. Yet, what is fundamental to a due process challenge is, of course, the nature of the right of which plaintiff has been deprived, not the availability of a remedy when that right is breached.

The perspective on governmental action adopted here emphasizes the need for a more sophisticated analysis of the due process rights in Baker and Parratt. Due process is a restraint on governmental action; internal procedures to monitor that action will often be necessary to satisfy its purposes. As with other constitutional guarantees, the requirements of due process must be adapted to the context in which they are asserted. ${ }^{\text {s3 }}$

\section{Protecting Constitutional Rights Through a Theory of Responsibil- ity for Constitutional Wrongs}

The model of a constitutional tort action that emerges from the preceding analysis is very different from the present version of the suit. Firmly oriented toward the observable processes of government, the analysis readily accommodates wrongdoing that is institutional in nature. The scope of liability is broader than current doctrine allows, but this expansion is controlled and remains within principled bounds.

63. In a similar way, the Fourth Amendment prohibition against unreasonable searches and seizures now extends to include illegal electronic surveillance. See Halperin v. Kissinger, 606 F.2d 1192 (D.C. Cir. 1979), aff'd by an equally divided court, 452 U.S. 713 (1981). First Amendment analysis has had to grapple with modern problems of access. See, e.g., Lehman v. City of Shaker Heights, 418 U.S. 298 (1974) (mere acceptance of commercial advertising does not require acceptance of political advertising as well); Miami Herald Publishing Co. v. Tornillo, 418 U.S. 241 (1974) (invalidating "right of reply" statute); Columbia Broadcasting Sys. v. Democratic Nat'l Comm., 412 U.S. 94 (1973) (broadcasters need not accept paid editorial advertisements). 


\section{A. The Constitutional Tort Action}

Under the scheme of liability proposed here, a plaintiff could charge a governmental entity or its responsible officers ${ }^{64}$ with negligence when challenging the conduct of front-line employees in a constitutional tort suit. In such cases, the plaintiff would not need to prove the offending subordinate's knowledge or state of mind. In order to establish a prima facie case, a plaintiff would allege facts to support the contention that the defendant was responsible for the harm because its policies or procedures were unreasonable; that is, these policies or procedures could not reasonably have been expected to prevent the constitutional violation. At the pretrial stage, the court should be mindful of the disadvantage under which a plaintiff labors in attempting to prove an organizational wrong. ${ }^{.8}$

If the plaintiff has made out a prima facie case of constitutional unreasonableness, the case must go to trial. There, the burden shifts to the defendant to justify its procedures and practices as non-negligent by demonstrating that they could reasonably have been expected to prevent the alleged violation of constitutional rights, or, in the case of due process claims, improper deprivations of life, liberty, or property. In assessing the acts of the relevant upper-level officials, the court may inquire into whether they sought legal advice before making decisions that implicated constitutional rights; ${ }^{\theta 6}$ the extent to which they promulgated precise rules

64. Under the scheme of liability proposed here, both government and individual official immunity would be abandoned. Commentators advocating this step include Foote, Tort Remedies for Police Violations of Individual Rights, 39 MINN. L. REV. 493, 514-15 (1955); Jaffe, Suits Against Governments and Officers: Damage Actions, 77 HARV. L. REV. 209, 229-30 (1963); Kattan, supra note 22, at 1000-02; Newman, supra note 58 , at 457 ; Schuck, supra note 8 , at $348-68$.

65. Limited discovery may sometimes be necessary for a complaint to survive a motion to dismiss, although many meritorious fact patterns will not require it. If requested to order discovery after this stage, the court should err on the side of liberality. While this may increase the burden on the governmental defendant, in this area of law the government may rightly be burdened. With respect to the concern that federal courts will be overburdened by constitutional tort litigation, Justice Harlan has asserted:

Judicial resources, I am well aware, are increasingly scarce these days. Nonetheless, when we automatically close the courthouse door solely on this basis, we implicitly express a value judgement on the comparative importance of classes of legally protected interests. And current limitations upon the effective functioning of the courts arising from budgetary inadequacies should not be permitted to stand in the way of the recognition of otherwise sound constitutional principles.

Bivens v. Six Unknown Named Agents of the Fed. Bureau of Narcotics, 403 U.S. 388, 411 (1971) (Harlan, J., concurring).

66. The contours of a legal knowledge requirement for certain governmental officials are explored in Freed, supra note 58, at 557; Kattan, supra note 22, at 994-95; cf. Owen v. City of Independence, 445 U.S. 622, 656 (1980) ("To criticize section 1983 liability because it leads decisionmakers to avoid the infringement of constitutional rights is to criticize one of the statute's raisons d'être.") (citation omitted). Cases requiring policymakers to seek legal advice include Shifrin v. Wilson, 412 F. Supp. 1282 (D.D.C. 1976); Zweibon v. Mitchell, 516 F.2d 594, 677-78 (D.C. Cir. 1975) (Bazelon, J., concurring in part and dissenting in part), cert. denied, 425 U.S. 944 (1976); McCray v. Burrell, 516 F.2d 357 (4th Cir. 1975), cert. dismissed as improvidently granted, 426 U.S. 471 (1976); Schiff v. Williams, 519 F.2d 257, 261 (5th Cir. 1975); see also United States ex rel. Tyrrell v. Speaker, 535 
to guide the conduct of front-line employees in sensitive areas; ${ }^{67}$ and the degree to which they enforced these rules with internal monitoring, supervision, and training. ${ }^{88}$ In addition, the court may look into the presence and adequacy of disciplinary mechanisms and grievance procedures to ensure responsiveness to wrongdoing. ${ }^{69}$ In short, the court may examine a broad range of administrative authority before it deems the governmental conduct "reasonable" with respect to plaintiff's constitutional rights. Only if the defendant can prove that the wrong was not due to its negligence-that is, to inadequate procedures, training, supervision, or internal enforcement measures ${ }^{70}$ - will it be absolved of liability for the acts of its employees. ${ }^{71}$

F.2d 823, 828 (3d Cir. 1976) (where defendant offered no evidence of reliance upon "state statute, court order or the general law," good faith defense not available).

67. Cf. Gomez v. Turner, 672 F.2d 134 (D.C. Cir. 1982) (although general order not facially invalid, defendant police department must prove reasonableness of practices employed under it involving questioning of pedestrians).

68. It cannot be urged too strongly that the purpose of this inquiry would not be to ensure that a public agency has adequate regulations "on the books." At trial the court must look for both the existence and the enforcement of satisfactory regulations. For cases involving such an inquiry, see Withers v. Levine, 615 F.2d 158, 162 (4th Cir.), cert. denied, 449 U.S. 849 (1980); McClelland v. Facteau, 610 F.2d 693, 697-98 (10th Cir. 1979); Salinas v. Breier, 517 F. Supp. 1272, 1277-79 (E.D. Wis. 1981); Brandon v. Allen, 516 F. Supp. 1355, 1358-61 (W.D. Tenn. 1981).

69. See Turpin v. Mailet, 579 F.2d 152 (2d Cir.) (municipality that did not discipline police officer judged liable in a section 1983 suit, but rather promoted him, held liable for sanctioning unconstitutional acts), vacated sub nom. City of West Haven v. Turpin, 439 U.S. 974 (1978), rev'd sub nom. Turpin v. Mailet, 619 F.2d 196 (2d Cir. 1980); see also Herrera v. Valentine, 653 F.2d 1220 (8th Cir. 1981) (where many complaints filed against police for brutality against minorities and city does nothing, official policy exists).

70. Compare Patzig v. O'Neil, 577 F.2d 841 (3d Cir. 1978) (no supervisory liability where plaintiff committed suicide during five-hour detention pending arraignment for drunk driving; breath test administered indicated intoxication) with Dewell v. Lawson, 489 F.2d 877 (10th Cir. 1974) (reversing dismissal of complaint against defendant police chief where plaintiff jailed four days as common drunk until found in diabetic coma; plaintiff was carrying medical identification and wife had alerted police of husband's absence and serious medical condition).

71. If, instead, the injury is attributable to an abuse of authority by a single official apparently not traceable to supervisory or organizational shortcomings, the plaintiff may seek to hold that official individually liable, again alleging the constitutional unreasonableness of his official behavior. To reiterate, this is not an allegation of common law negligence; indeed, a plaintiff instituting such an action against an individual official will most likely be challenging intentional acts constituting an abuse of official authority. As the authority wielded by the defendant official is governmental, not personal, he will have to defend its use as reasonable with reference to objective standards; a good faith reasonable belief alone will not suffice. In such a case, the damage award should be calculated with an eye to individual deterrence, and the individual official should be required to pay. Only if the award is insufficient to cover plaintiff's special damages should the government step in to assist in compensation.

As a third and final scenario, injury may be the result of common law negligence, or non-negligent conduct on the part of an individual official that is not traceable to a breach of a governmental duty. In such a case, although the error may be a violation of a common law standard of care, it is not an abuse of governmental authority that is unreasonable from a constitutional standpoint. Under such circumstances, plaintiff can be compensated by a governmental scheme established as a matter of policy.

The example in the text as well as the two situations described in this footnote involve the misapplication of official power. The first two, however, describe instances of constitutional unrcasonableness, while only the last includes violations of an individual's common law duty of care. Both types of 
From the plaintiff's perspective, the proposed approach would alleviate the difficulty of choosing appropriate individual defendants. ${ }^{72}$ Furthermore, levying the sanction in the first instance upon the government entity would encourage fine tuning of administrative controls over individual conduct. $^{73}$ Attention to wrongful governmental conduct would also make more prominent the role of deterrence in assessing damages. Traditionally, compensation has guided the imposition of both common law and constitutional tort damage awards. ${ }^{74}$ Compensation, however, is often inadequate to achieve the purposes of the constitutional tort action. For instance, many constitutional rights involve the right to be free of certain infringements of important but intangible interests: The violation of First, Fourth, Fifth, and Fourteenth Amendment rights may produce minimal tangible injury and thus no special damages. ${ }^{75}$ Recognition of deterrence

"constitutional negligence" may actually involve acts that are, in common law terminology, intentional. Indeed, failure at the supervisory level frequently results in intentional abuses by subordinates. Damage awards in such cases have a remedial and a deterrent purpose. On the other hand, damages in the third type of action are, as at common law, to compensate for injury. Although of the same genus, these three types of claims against governmental defendants are not of the same species.

72. Cf. Howell v. Cataldi, 464 F.2d 272 (3d Cir. 1972) (affirming directed verdict for police officer defendants where plaintiff who was beaten by police while in diabetic coma produced eyewitness testimony of incident but insufficient identification testimony to prove named defendants were participants); see also Duncan v. Duckworth, 644 F.2d 653, 655 (7th Cir. 1981) (nominally responsible superior may be required to name official with actual responsibility).

73. As the Supreme Court observed in Owen v. City of Independence, 445 U.S. 622 (1980):

[T] The threat that damages might be levied against the city may encourage those in a policymaking position to institute internal rules and programs designed to minimize the likelihood of unintentional infringements on constitutional rights. Such procedures are particularly beneficial in preventing those "systemic" injuries that result not so much from the conduct of any single individual, but from the interactive behavior of several government officials, each of whom may be acting in good faith.

Id. at 652 (citations omitted); see also Schuck, supra note 8, at 361-68 (proposing ways in which administrative controls over officials could be strengthened to provide optimal mix of deterrence and vigorous decisionmaking).

74. See Robertson v. Wegemann, 436 U.S. 584, 590-91 (1978); Carey v. Piphus, 435 U.S. 247, 254-59 (1978). There are indications that Supreme Court thought in this area may be changing. In Owen v. City of Independence, 445 U.S. 622, $651-52$ (1980), the Court acknowledged that the goals of deterrence and compensation are both served by constitutional tort damage awards. Although the Court has declared that punitive damages are not available against municipal defendants, City of Newport v. Fact Concerts, Inc., 453 U.S. 247 (1981), it recently upheld such an award against an individual defendant. See Smith v. Wade, 103 S. Ct. 1625 (1983) (although no evidence of ill will or spite by correctional officer toward inmate, award of punitive damages was appropriate where officer recklessly placed dangerous prisoner in inmate's cell).

75. In such cases, some courts have responded by expanding the grounds for compensation beyond out-of-pocket losses. See, e.g., Halperin v. Kissinger, 606 F.2d 1192, 1207-08 (D.C. Cir. 1979) (plaintiff may be able to prove "loss due to emotional distress and mental anguish" resulting from illegal wiretap), affd by an equally divided court, 452 U.S. 713 (1981); Tatum v. Morton, 562 F.2d 1279, 1282 (D.C. Cir. 1977) (right to demonstrate on public issues requires "reasonably spacious" approach to compensation); Paton v. La Prade, 524 F.2d 862, 868, 870-71 (3d Cir. 1975) (plaintiff may be able to prove as damages arising out of FBI investigation stigmatization, invasion of privacy, interference with personality development and associational rights, and endangerment of educational and employment opportunities); Jenkins v. Averett, 424 F.2d 1228, 1233 (4th Cir. 1970) (plaintiff wrongfully shot by police officer should recover for pain and suffering and inability to engage in high school athletics). The difficulties associated with constitutional tort damage awards based on compen- 
as the primary end to be accomplished through the constitutional damage action would provide the courts with firmer guidance in determining damages in such suits, and would affirm the value of constrained government embodied in the constitutional tort action.

\section{B. Constitutional Tort Duty in Application}

Under the framework of responsibility laid out here, Baker v. McCollan and Parratt v. Taylor would be analyzed very differently. The authority to imprison by force is a necessary and coercive corollary to the state police power. It is also a government function that usually is carried out through routine procedures: An individual is "booked" and processed through the pretrial detention system. In charging the sheriff with negligence under the due process clause, the plaintiff in Baker v. McCollan was alleging that he had breached a Fourteenth Amendment duty to establish procedures that could reasonably be expected to protect plaintiff's constitutional liberty interests. ${ }^{76}$ The sheriff was under an obligation not only to obtain a constitutionally valid warrant, but also to devise and enforce procedures designed to ensure the speedy and accurate identification of detainees. The sheriff's office in Baker had no identification procedures. In response to plaintiff's complaint, the sheriff should have borne the burden of defending their absence, and of explaining how the office's action-or inaction-during plaintiff's seven-day incarceration was reasonable with respect to his constitutional rights. ${ }^{77}$

sation may be somewhat alleviated by the Supreme Court's recent decision affirming the award of punitive damages against a correctional officer sued under section 1983. See Smith v. Wade, $103 \mathrm{~S}$. Ct. 1625 (1983). But see City of Newport v. Fact Concerts, Inc., 453 U.S. 247 (1981) (punitive damages are not available against municipal defendants sued under section 1983).

76. The circuit court opinion aptly summarized the sheriff's constitutional obligation:

We are not saying that a sheriff is under a duty to make an independent investigation as to the guilt or innocence of a person wanted under a warrant .... We are saying that the sheriff ... has a duty to exercise due diligence in making sure that the person arrested and detained is actually the person sought under the warrant and not merely someone of the same or a similar name.

McCollan v. Tate, 575 F.2d 509, 513 (5th Cir. 1978), rev'd sub nom. Baker v. McCollan, 443 U.S. 137 (1979); $c f$. Bryan v. Jones, 530 F.2d 1210, 1215 (5th Cir.) (en banc) (jailer who has no discretion as to wrongful confinement and is under very little time pressure will be held to high level of reasonableness in his actions), cert. denied, 429 U.S. 865 (1976).

77. The court of appeals commented:

The Potter County Sheriff's Department did not send the mugshots and fingerprints of Leonard McCollan which it had in its files. Nor did the sheriff's deputies who drove to Dallas to pick up the plaintiff take this identifying material with them. When the deputies brought plaintiff to the Potter County Jail on December 30, no one was on duty in the Identification Department, and no one compared plaintiff with the photographs and fingerprints on file. Had [they] been sent or carried to Dallas or had the identifying information in the file at the sheriff's office been checked, the mistake would have been evident. Although plaintiff is Leonard's brother, he does not resemble Leonard in appearance.

McCollan v. Tate, 575 F.2d 509, 511 (5th Cir. 1978), rev'd sub nom. Baker v. McCollan, 443 U.S. 137 (1979). 
The prison in Parratt had custody of the plaintiff's property ${ }^{78}$ It failed first to deliver it in accordance with prison procedures, and then to respond to the plaintiff's formal grievances as required by established rules. As the Court so forcefully argued in its decision, common law negligence and other unauthorized deprivations of liberty and property are inevitable in a bureaucracy and make provision of a prior hearing impossible. Nonetheless, many unauthorized acts, both negligent and intentional, are certainly preventable by "processes" instituted by the government employer: the promulgation of effective regulations, the provision of adequate training and supervision, the adoption of internal grievance mechanisms to alert the organization to malfunctions in the system, the establishment of procedures that direct victims of employee negligence to prompt compensation mechanisms.

It is to these processes, including plaintiff's unsuccessful attempts to secure his property through institutional channels, that the Court in Parratt should have looked in determining whether plaintiff's constitutional interest in not being deprived of property without due process of law had been adequately safeguarded by the defendant prison officials. Unless the manner in which the prison handled plaintiff's incoming mail and its loss were found to be constitutionally reasonable, the plaintiff in this case would prevail on his negligence claim. ${ }^{29}$

\section{Conclusion}

As a result of its inadequate explanation of cause and responsibility for many alleged wrongs, traditional constitutional tort theory provides incomplete protection for constitutional rights. Present Supreme Court treatment of allegations of negligence against supervisory government defendants exposes this flaw most clearly. The framework developed here should point the way to a legal doctrine that is theoretically coherent and more solicitous of the concerns that should be vindicated through the constitutional tort action.

78. Although the Court in Parratt began its analysis by noting that the missing hobby material was of little monetary value, the fact that the compensable injury was small concededly had no constitutional significance. Parratt v. Taylor, 451 U.S. 527, 529 (1981). It does not trivialize the constitutional damage action to bring a case to trial where the government's conduct is on its face wrongful.

79. Cf. Kimbrough v. O'Neil, 545 F.2d 1059, 1061-62 (7th Cir. 1976) (Swygert, J., dissenting) (original taking of inmate's diamond ring was under color of law; unexplained nonreturn constituted deprivation of property without due process; plaintiff should not have impossible task of proving that conversion was "intentional"); Carter v. Estelle, 519 F.2d 1136 (5th Cir. 1975) (supervisors may be held liable for wrongful taking by guards of inmate property). 